\title{
A Study on the Protective Effects of Zinc Sulphate, Nicotinic Acid and Nigella Sativa on Alcohol Induced Gastric Lesion in Male Albino Rats
}

\author{
Mahmoud A. EI-Gharieb and *Thanaa A. El-Masry \\ Department of Physiology, Faculty of Medicine \\ *Department of Pharmacology, Faculty of Pharmacy, Tanta University
}

\begin{abstract}
The present study was conducted to study the protective effects of zinc suiphate (ZnS), nicotinic acid (NA) and Nigella sativa on the alcohol induced gastric lesion in male albino rats. The study was carried out on (48) adult male albino rats weighing 200250 gms. The rats were divided into two equal groups, then. Each group was subdivided into four equal subgroups. Group (A): The normal rats which are subdivided into: subgroup (l): control group subgroup (2): the rats were intraperitoneally injected by zinc sulphate subgroup (3) the rats were intraperitoneally injected by nicotinic acid and subgroup (4) the rats were orally administrated Nigella Sativa oil daily for two weeks. Group (B) The rats were subdivided into: subgroup (l): rats were administrated ethanol $40 \%$ orally for two weeks, subgroup; (2): the rats were administrated ethanol $40 \%$ orally and intraperitoneally injected by zinc sulphate, subgroup (3) the rats were administrated ethanol $40 \%$ oral!y and intraperitoneally injected by nicotinic acid and subgroup (4) the rats were administrated by ethanol $40 \%$ orally with Nigella Sativa oil orally daily for two weeks. After the last dose of each group, the animals were left for one hour then anaesthetized by ether. The gastric secretion was collected in the acute rat fistula. The abdomen was incised and both the stomach and the duodenum were exposed. The gastric secretion was collected for the analysis and sections were taken for histological examination. The results showed significant increase of gastric mucin content, and glutathione and significant decrease in the volume of the gastric secretion, peptic activity, free acidity and gastric histamine content in ethanol induced gastric lesion with either zinc sulphate, nicotinic acid and Nigella Sativa oil. histopathological picture showed improvement of hemorrhage, edema and increase in the mucus layer thickness and regeneration of the gastric mucosal erosion. It is recommended to increase the administration of zinc sulphate, nicolinic acid and Nigella Sativa to patients with gastric ulcer.
\end{abstract}

\section{INTRODUCTION}

The gastric mucosa is exposed to a specially highly acidic and proteolytic juice. It would be auto digested without the strong protective barrier of the mucosa. Peptic ulcer is an excoriated area of the gastric mucosa due to auto digestion by the gastric juice. The main cause of peptic ulcer is an imbalance between gastric 
acidity and the protective mucosal barrier $^{[1]}$.

Alcoholism is an illness caused by consumption of alcohol beverages at a level that interferes with physical or mental health, social, familial and occupational responsibility. People with alcohol dependence have to increase markedly amounts of alcohol to achieve the desired effect or intoxication $^{[2]}$. Alcoholism affects from 15 to 20 million American and affects three to four times as many family members, coworkers and friends. It is involved in half of all fatal automobile accidents and is responsible for more than 100,000 deaths annually, representing about $5 \%$ of all deaths in the United States. Fetal alcohol syndrome is the third leading cause of birth defects with accompanying mental retardation ${ }^{[3]}$. Acute and chronic alcoholism carry the potential damage to many organs of the body including the heart, brain, liver, kidney, digestive system and reproductive system (erectile dysfunction and cessation of menstruation). When alcohol was given, its level in the body increased and produced the toxic effects ${ }^{[3]}$.

Zinc is essential in normal growth, reproduction and has a beneficial effect on the process of tissue repair and wound healing. Zinc is a constituent of the antioxidant super oxide dismutase. It is also needed for proper maintenance of vitamin $\mathrm{E}$ level in the blood and aids in the absorption of vitamin $\mathrm{A}^{\mathbf{1 5 1}}$. It exerts a protective effect and possibly preventing cellular damage caused by oxidative stress ${ }^{[6]}$. Zinc metalloenzymes includes 200 related enzymes for which zinc is needed, that participates in the metabolism of lipids, carbohydrates, synthesis of proteins and nucleic acids. Zinc has a metabolic role under various physiological and pathological conditions ${ }^{\mathbf{1 7 1}}$. Both zinc and copper are cofactors in the metalloenzymes $\mathrm{Cu}^{+2}, \mathrm{Zn}^{+2}$ super oxide dismutase and zinc competes with $\mathrm{Cu}^{+2}$ for the binding sites ${ }^{[8]}$

Nicotinic acid is also known as niacin, a term is used to avoid confusion between it and the alkaloid nicotine. NAD and NADP, the physiological active forms of nicotinic acid, serve a vital role in metabolism as coenzymes for wide variety of proteins that catalyze oxidationreduction reactions essential for tissue respiration. Nicotinic acid is sometimes used in the treatment of hyperlipoproteinemia. The process of atherogenesis or thrombosis may be influenced by the substantial reduction of circulating fibrinogen levels produced by niacin and the level of tissue plasminogen activator seems to increase' ${ }^{1}$. Black seed (Nigella Sativa) is a member of Runuculaceae family. It is one of the native plants that are widely distributed in Egypt. Nigella Sativa and its constituents have been widely used in folk medicine and experimental animal studies ${ }^{\mathbf{1 0 1}}$. In Arabian folk medicine, it is used for treatment and prevention of many diseases like bronchial asthma, rheumatism and hypertension. Also, Nigella Sativa was used to elevate the immunity ${ }^{[11]}$ Nigella Sativa seeds and its constituents have antioxidant action (capable of scavenging oxygen derived free radicals), digestive stimulant and an immune modulating effect. Also Nigella sativa has cyto- 
proteclive effect on tissue exposed to cyto-toxic agents ${ }^{[11,12]}$

The present work was done to study the protective effects of zinc sulphate, nicotinic acid and Nigella Sativa oil as cytoprotective agents against local irritant effect and oxidative gastric mucosal damage induced by alcohol in male albino rats.

\section{MATERIALS \& METHODS}

The present study was carried out on (48) adult male albino rats weighting 200-250 gms, kept for two weeks under optimal environmental conditions for accommodation. Rats were fed on a diet consisting of wheat and bread soaked in milk. The animals had free access to water. The rats were divided into two equal groups:

Croup (A): which divided into 4 equal subgroups each containing 6 rats;

- Subgroup (l): The animals were administrated intraperitoneally $1 \mathrm{ml}$ saline daily for two weeks and served as control group.

- Subgroup (2): The animals were administrated intraperitoneally by zinc sulphatc (Octozinc-October Pharma Company, Egypt) in a dose of $40 \mathrm{mg} / \mathrm{kgm}^{[13]}$ for two weeks.

- Subgroup (3): The animals were administrated intraperitonealy nicotinic acid(Sigma Chemical Company) in a dose of $50 \mathrm{mg} / \mathrm{kg}^{[14]}$ for two weeks,

- Subgroup (4): The animals received oral Nigella Sativa oil(Pharco- Pharmaceutical Alexandria-Egypt) in a dose of 0.88 $\mathrm{ml} / \mathrm{kg}^{[12]}$ daily for two weeks.
Group (B): Which is divided into four equal subgroups each containing 6 rats:

- Group (5): The animals were administrated $3 \mathrm{ml}$ of $40 \%$ ethanol (ethyl alcohol) orally daily for two weeks $^{[12]}$ (by oro-gastric tube).

- Group(6): The animals were administrated zinc sulphate intraperitonealy a dose of $40 \mathrm{mg} / \mathrm{kg}$ twenty minutes before giving ethanol $40 \%$ in a dose of $3 \mathrm{ml}$ administrated for two weeks.

- Group (7): The animals were administrated nicotinic acid intraperitonealy in a dose of $50 \mathrm{mg} / \mathrm{kg}$ twenty minutes before giving ethanol $40 \% 3 \mathrm{ml}$ for two weeks.

- Group (8): The animals were administrated oral Nigella Saliva oil in a dose of $0.88 \mathrm{ml} / \mathrm{kg}$ twenty minutes before giving ethanol $40 \%$ $3 \mathrm{ml}$ for two weeks.

The animals were kept fasting 18 hours before any daily dose (except for water) to avoid mixing of food with the gastric secretion. After the last dose of each group, the animals were left for one hour then anaesthetized by ether. The gastric secretion was collected in the acute rat fistula ${ }^{[15]}$ briefly the abdomen was incised and both the stomach and the duodenum were exposed. An acute fistula (inside diameter $=3 \mathrm{~mm}$ ) was made with polythene tube inserted into the stomach through a small incision made in the duodenum and held in place by a ligature around the pylorus. The esophagus was clamped to prevent reflux and loss of gastric secretion, the gastric secretion was collected every hour for four consecutive hours after administration 
of the last dose to get enough amounts of secretion for the analysis. The following parameters were determined:

1-Volume of gastric secretion and gastric free acidity according to the method of Varet ${ }^{[16]}$

2-Determination of mucin content of gastric juice according to the method of Richard ${ }^{[17]}$

3-Determination of peptic activity according to the method of (Sanyal et al) ${ }^{[18]}$

4-Estimation of gastric mucosal histamine by fluorometric method $\left(\right.$ Lorenz et al) ${ }^{[19]}$.

5-Estimation of gastric glutathione content by the method of Owens and Belcher ${ }^{[20]}$

6-Histological procedures: The gastric tissue samples were preserved in $10 \%$ buffered formalin and processed for paraffin block preparation- These sections were examined for histological changes.

\section{Statistical Analysis}

Group A results were compared by the control included ethanol subgroup. Group B were compared by ethanol one. Student's "T" test was used for the evaluation of statistical significance. Differences was considered significant at $\mathrm{P}<0.05$ level. All values were expressed as mean \pm SD.

\section{RESULTS}

The results of the present work are demonstrated in table (1) and (2)

1-Effects of administration of intraperitoneal zinc sulphate to normal male albino rats showed significant decrease of the volume of the gastric secretion, histamine content and free acidity $(\mathrm{P}<0.05)$. There was a significant increase of gastric mucin and glutathione content $\quad(\mathrm{P}<0.05)$, but non significant decrease of peptic activity $(\mathrm{P}>0.05)$ in relation to control group (table 1 ).

2- Effects of administration of intraperitoneal nicotinic acid to normal male albino rats showed significant decrease of the volume of the gastric secretion, histamine content and free acidity $(\mathrm{P}<0.05)$. There was a significant increase of gastric mucin and glutathione content $(\mathrm{P}<0.05)$, but non significant decrease of peptic activity $(\mathrm{P}>0.05)$ in relation to control group (table 1$)$.

3-Effects of administration of oral Nigella Sativa oil to normal male albino rats showed significant decrease of the volume of the gastric secretion, histamine content and free acidity $(\mathrm{P}<0.05)$. There was a significant increase of gastric mucin and glutathione content $\quad(\mathrm{P}<0.05)$, but non significant decrease of peptic activity $(\mathrm{P}>0.05)$ in relation to control group, (table 1)

4- Effect of oral administration of ethanol to normal male albino rats showed significant increase of the volume of gastric secretion, peptic activity, histamine content and free acidity $(\mathrm{P}<0.05)$. There was a significant decrease of gastric mucin and glutathione content compared to the control group $(\mathrm{P}<0.05)$, (tables 1,2$)$.

5- Effect of oral administration of ethanol $40 \%$ and intraperitoneal zinc sulphate to male albino rats showed significant increase of 
gastric mucin content and glutathione $(\mathrm{P}<0.05)$. There was significant decrease in the volume of the gastric secretion, peptic activity, free acidity and gastric histamine content $\left(\mathrm{l}^{\prime<}<0.05\right)$ compared to the ethanol group, table (2).

6- Effect of oral adiminstration of ethanol $40 \%$ and intraperitoneal nicotinic acid to narmal male albino rats showed significant increase of gastric mucin content and glutathione $(\mathrm{P}<0.05)$. There was significant decrease in the volume of the gastric secretion, free acidity, peptic activity and gastric histamine content $(\mathrm{P}<0.05)$ compared to ethanol group, table (2).

7- Effect of oral administration of ethanol $40 \%$ and oral Nigella Sativa oil to normal male albino rats, showed significant increase of gastric mucin content and glutathione $(\mathrm{P}<0.05)$. There was significant decrease in the volume of the gastric secretion, free acidity, peptic activity and gastric histamine content $(\mathrm{P}<0-05)$ compared to the ethanol group, table (2), There were also significant increase of gastric mucin and glutathione content of rats treated by ethanol and Nigella Sativa oil compared to zinc sulphate and nicotinic acid group $(\mathrm{P}<0,05)$.

Histopathological examination:

1-Control stomach: Fig. (1).

The Gastric mucosa of normal rats showed numerous gastric pits and normal arrangement of gastric glands.
Examination of sections of gastric mucosa of the rats administrated ethanol with Hx\& E showed shedding of all layers of gastric mucosa, severe distortion of gastric glands with inflammatory cells infiltration (mainly neutrophils), Also edema and severe submucosal vasodilatation were noticed. There is also decrease in the mucus content of the gastric epithelial cells as compared with section of normal control group. Fig. (2,3).

\section{2-Effect of intraperitoneal adminstration of zinc sulphate and oral ethanol.}

Examination of gastric sections stained with Hx\&E showed improvement in the gastric mucosa in the form of healing of the gastric mucosa and gastric glands .reduction of neutrophlic infiltration and sub mucosal edema as compared with ethanol group. Fig. (4).

\section{3-Effect of intraperitoneal administration of nicotinic acid and oral ethanol.}

Examination of gastric section stained with $\mathrm{Hx} \& \mathrm{E}$ showed decrease and improvement of hemorrhage and edema and an increase in the mucus layer thickness and regeneration of the gastric mucosal erosion, Fig. (5).

4-Effect of oral administration of Nigella Sativa oil and oral ethanol

Examination of gastric section stained with Hx\&E showed increase in the gastric glands and return of the gastric glands to near the control pattern. There are little evidences of hemorrhage, edema and erosion, Fig. (6). 
Table (1): Effects of zinc sulphate, nicotinic acid and Nigella Sativa oil on the gastric volume (ml/hour), mucin content (mg hexose \%), peptic activity (uEq/L), histamine content $\mathrm{mg} / \mathrm{gm}$ tissue), Glutathione (mg/gm tissue) and free acidity $(\mathrm{mEq} / \mathrm{L})$, in normal male albino rats.

\begin{tabular}{|c|c|c|c|c|c|c|}
\hline Parameter & $\begin{array}{l}\text { Volume } \\
\mathrm{ml} / \mathrm{hour} \\
\text { (mean } \\
6 \pm \mathrm{SD})\end{array}$ & $\begin{array}{l}\text { Mucin } \\
\text { content } \\
\text { mg hexose } \\
\% \text { (mean } \\
6 \pm \text { SD) }\end{array}$ & 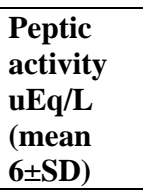 & $\begin{array}{l}\text { Histamine } \\
\text { content } \\
\text { mg/gm } \\
\text { tissue (mean } \\
6 \pm \mathrm{SD} \text { ) }\end{array}$ & $\begin{array}{l}\text { Glutathione } \\
\text { content } \\
\text { mg/gm } \\
\text { tissue (mean } \\
6 \pm \text { SD) }\end{array}$ & $\begin{array}{l}\text { Free } \\
\text { acidity } \\
\text { mEq/L } \\
\text { (mean } \\
\pm \text { SE) }\end{array}$ \\
\hline $\begin{array}{l}\text { Control } \\
\text { group }\end{array}$ & $1.54 \pm 0.13$ & $51.95 \pm 1.65$ & $80 \pm 1.44$ & $32.8 \pm 1.87$ & $0.68 \pm 0.01$ & $21.8 \pm 0.66$ \\
\hline $\begin{array}{l}\text { Zinc } \\
\text { Sulphate } \\
\mathrm{t}\end{array}$ & $\begin{array}{l}1.37 \pm 0.05 \\
3.2 *\end{array}$ & $\begin{array}{l}61.01 \pm 2.75 \\
1.12 *\end{array}$ & $\begin{array}{l}79.71 \\
1.53\end{array}$ & $\begin{array}{l}26.96 \pm 1.81 \\
5.5^{*}\end{array}$ & $\begin{array}{l}0.81 \pm 0.11 \\
1.11 *\end{array}$ & $\begin{array}{l}16.4 \pm 0.75 \\
3.5^{*}\end{array}$ \\
\hline $\begin{array}{l}\text { Nicotinic } \\
\text { acid } \\
\mathrm{t}\end{array}$ & $\begin{array}{l}1.33 \pm 0.08 \\
3.3 *\end{array}$ & $\begin{array}{l}60.05 \pm 2.75 \\
1.42 *\end{array}$ & $\begin{array}{l}78.1 \pm 1.31 \\
1.13\end{array}$ & $\begin{array}{l}25.73 \pm 1 \\
7 *\end{array}$ & $\begin{array}{l}0.78 \pm 0.23 \\
1.25 *\end{array}$ & $\begin{array}{l}17.2 \pm 0.96 \\
3.4^{*}\end{array}$ \\
\hline $\begin{array}{l}\text { Nigella } \\
\text { Sativa } \\
\text { t }\end{array}$ & $\begin{array}{l}1.34 \pm 0.04 \\
3.1^{*}\end{array}$ & $\begin{array}{l}60.15 \pm 3.47 \\
1.21 *\end{array}$ & $\begin{array}{l}80 \pm 0.31 \\
1.51\end{array}$ & $\begin{array}{l}24.43 \pm 1.47 \\
6.6^{*}\end{array}$ & $\begin{array}{l}0.79 \pm 0.81 \\
1.35^{*}\end{array}$ & $\begin{array}{l}15.8 \pm 1 \\
3^{*}\end{array}$ \\
\hline
\end{tabular}

$*$ = Denotes statistical significance $(\mathrm{P}<0.05)$.

Table (2): Effects of zinc sulphate, nicotinic acid and Nigella Sativa oil on the gastric volume (ml/hour), mucin content (mg hexose \%), peptic activity (uEq/L), histamine content $\mathrm{mg} / \mathrm{gm}$ tissue), Glutathione (mg/gm tissue) and free acidity $(\mathrm{mEq} / \mathrm{L})$, in Ethanol induced gastric lesion in male albino rats.

\begin{tabular}{|c|c|c|c|c|c|c|}
\hline Parameter & 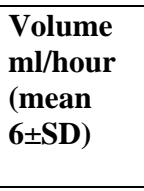 & $\begin{array}{l}\text { Mucin } \\
\text { content } \mathrm{mg} \\
\text { hexose \% } \\
\text { (mean } \\
6 \pm \mathrm{SD}) \\
\end{array}$ & 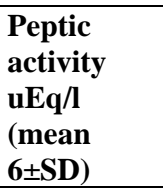 & $\begin{array}{l}\text { Histamine } \\
\text { content } \\
\text { mg/gm } \\
\text { tissue(mean } \\
6 \pm \text { SD) } \\
\end{array}$ & $\begin{array}{l}\text { Glutathione } \\
\text { content } \\
\text { mg/gm } \\
\text { tissue (mean } \\
6 \pm \text { SD) }\end{array}$ & $\begin{array}{l}\text { Free } \\
\text { acidity } \\
\text { mEq/L } \\
\text { (mean } \\
\pm \text { SE) } \\
\end{array}$ \\
\hline $\begin{array}{l}\text { Ethanol } \\
\mathrm{t}\end{array}$ & $\begin{array}{l}2.76 \pm 0.11 \\
20^{*}\end{array}$ & $\begin{array}{l}34.36 \pm 1 \\
13.5 *\end{array}$ & $\begin{array}{l}92.28 \pm 0.68 \\
3.2 *\end{array}$ & $\begin{array}{l}38 \pm 0.40 \\
4.7^{*}\end{array}$ & $\begin{array}{l}0.42 \pm 0.03 \\
36^{*}\end{array}$ & $\begin{array}{l}35.48 \pm 0.97 \\
9 *\end{array}$ \\
\hline $\begin{array}{l}\text { Ethanol } \pm \text { zinc } \\
\text { sulphate } \\
\text { t }\end{array}$ & $\begin{array}{l}1.95 \pm 0.08 \\
16^{*}\end{array}$ & $\begin{array}{l}41.83 \pm 0.65 \\
42.6^{*}\end{array}$ & $\begin{array}{l}80.2 \pm 0.33 \\
4.9 *\end{array}$ & $\begin{array}{l}30.35 \pm 0.65 \\
18.8^{*}\end{array}$ & $\begin{array}{l}0.51 \pm 0.13 \\
36 *\end{array}$ & $\begin{array}{l}24.88 \pm 0.87 \\
10 *\end{array}$ \\
\hline $\begin{array}{l}\text { Ethanol } \pm \\
\text { Nicotinic acid } \\
\mathrm{t}\end{array}$ & $\begin{array}{l}1.89 \pm 0.04 \\
21.7 *\end{array}$ & $\begin{array}{l}42.88 \pm 0.60 \\
43.6^{*}\end{array}$ & $\begin{array}{l}79.83 \pm 0.48 \\
5.5 *\end{array}$ & $\begin{array}{l}29.63 \pm 0.70 \\
19.9 *\end{array}$ & $\begin{array}{l}0.52 \pm 0.09 \\
40 *\end{array}$ & $\begin{array}{l}23.98 \pm 0.50 \\
12.7^{*}\end{array}$ \\
\hline $\begin{array}{l}\text { Ethanol+Nigell } \\
\text { a Sativa } \\
\text { t }\end{array}$ & $\begin{array}{l}1.99 \pm 0.15 \\
11 *\end{array}$ & $\begin{array}{l}49.5 \pm 0.66 \\
45 *\end{array}$ & $\begin{array}{l}79.05 \pm 0.45 \\
7.5 *\end{array}$ & $\begin{array}{l}28.35 \pm 0.76 \\
22.5 *\end{array}$ & $\begin{array}{l}0.59 \pm 0.1 \\
43 *\end{array}$ & $\begin{array}{l}22.86 \pm 0.61 \\
13.8 *\end{array}$ \\
\hline
\end{tabular}

$*=$ Denotes statistical significance $(\mathrm{P}<0.05)$. 


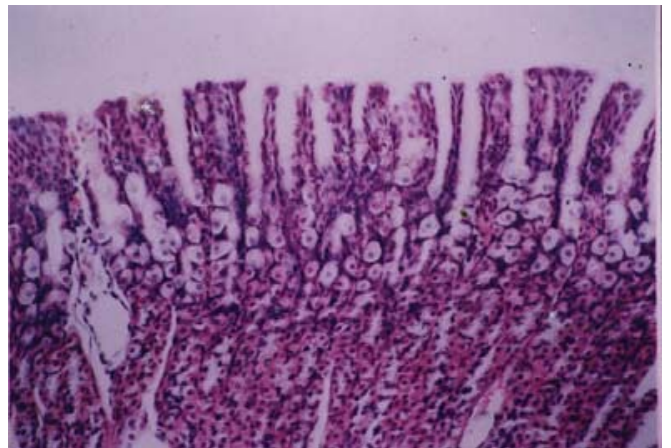

Fig. (1): Section of gastric mucosa of normal control rat showing numerus gastric pits and normal arrangement of gastric glunds [HX \& E X 200].

Fig. (2): Section of gastric mucosa of a rat administrated by alcho;l showing mucosal necrosis, unapparent gastric pits, patchy cellular infiltration and congested blood vessels [Hx \& EX 200].
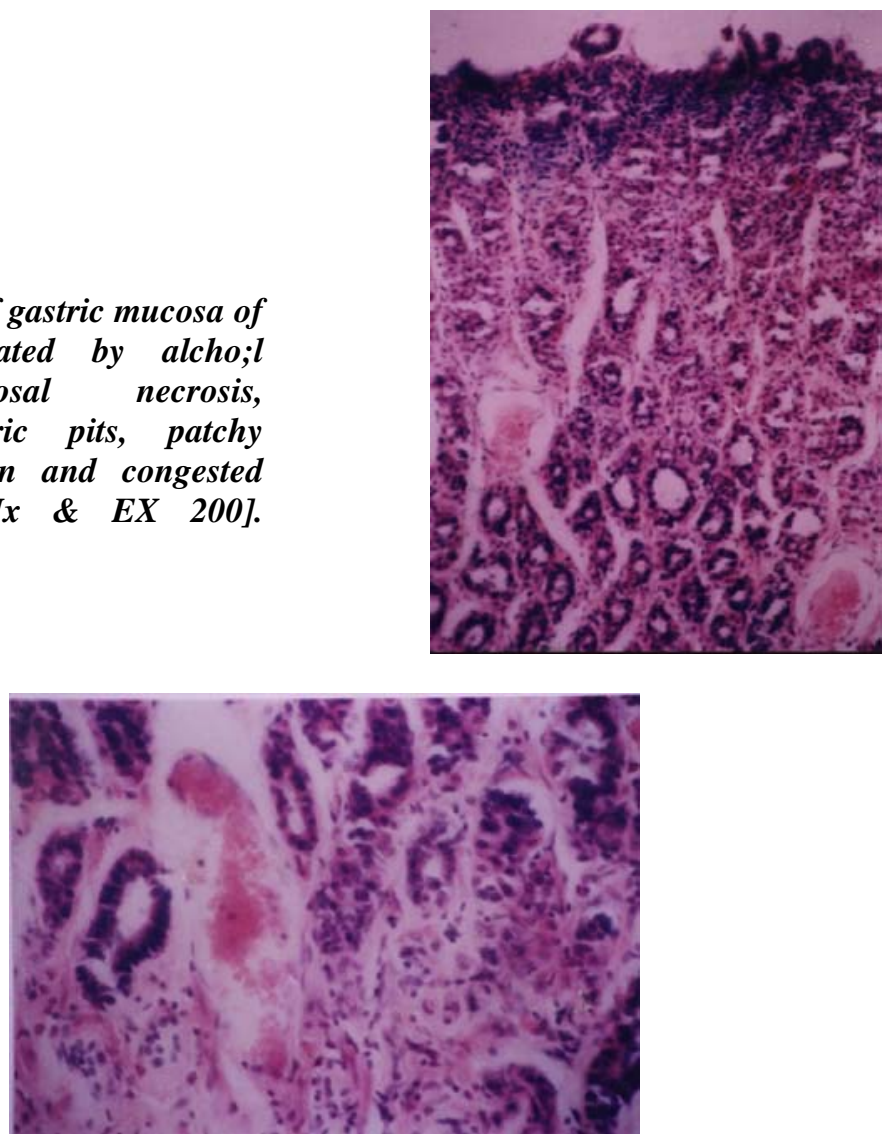

Fig. (3): Section of gastric mucosal of a rat treated by alcohol showing congested and dilated blood vessels [Hx \& EX 400]. 


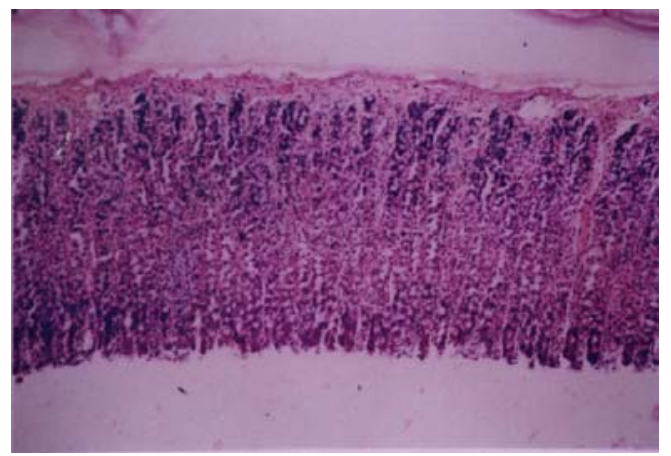

Fig. (4): Section of gastric mucosa of a rat treated by alcohol and zinc sulphate showing improvement of general architecture and no; evidence of congestion or edema [Hx \& E X 100].

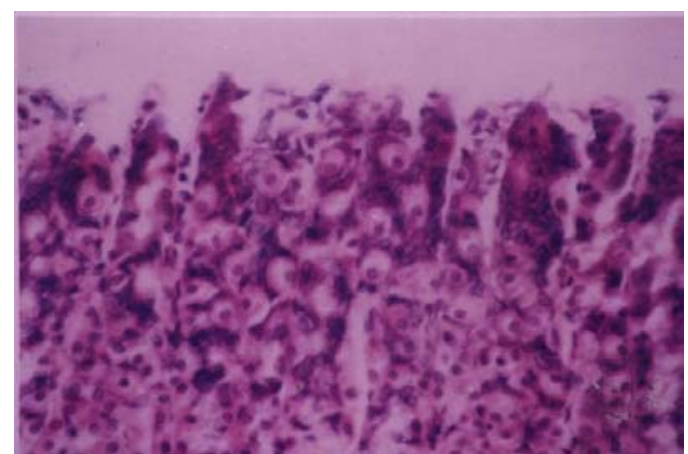

Fig. (5): Section of gastric mucosa of a rat treated by nicotinic acid and alcohol showing normal gastric pits and gastric glands and moderate increase of mucin lining the neck and base of the glands [Hx \& EX 400].

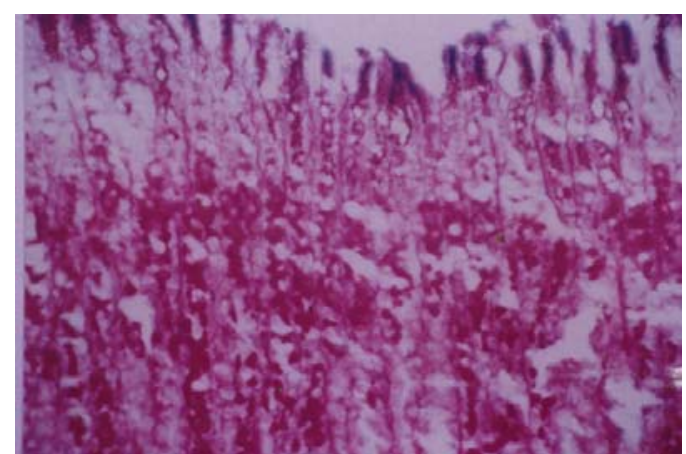

Fig. (6): Section of gastric mucosa of a rat treated by Nigella sativa oil and alcohol showing increased amount of mucin lining the glands normal gastric pits and little evidence of hemorrhage or edema [Hx \& E X 200]. 


\section{DISCUSSION}

Alcohol is the most abused drug in the United States and other countries. Alcohol carries the potential damage many organs of the body, including the heart, brain, liver digestive and the reproductive systems. Essential information about alcoholism had come from studies with animal showing sensitivities and responses to alcohol similar to those of humans, so animal models were selected in this work. Albino rats were selected because they have many of the same biological and behavioral reactions to alcohol as human ${ }^{[21]}$ The present study revealed increased mortality rate between rats administered alcohol alone but the rate decreased in rats which received simultaneously alcohol and zinc sulphate, nicotinic acid or Nigella Sativa oil at the same time. This was in agreement with Gamal, II. Al Sokkary ${ }^{[15]}$ who reported that, rats receiving alcohol for one month lost weight because alcohol stimulated leptin secretion. Leptin discovered in 1994, is the hormone that regulates appetite, Increased mortality rate is most probably due to malnutrition, liver disease and multi-organ affection resulting from alcoholism. The deficiency of prostaglandins(PGs) is widely accepted as a major factor in the pathogenesis of gastro-intestinal lesions, since small amount of exogenous (PGs) prevents the induction and further development of gastric ulceration $^{\text {[22] }}$

The results of the present study apparently showed the ulcerative effects of ethanol. The histopathology of the gastric mucosa showed also that ethanol induced congestion, hemorrhage, edema, erosion and necrosis. These results may be due to ethanol-induced depletion of gastric levels of proteins, nucleic acids and by the increased formation of free radicals that caused tissue damage by stimulating lipid peroxidation and membrane damage by' cross linkage of proteins, nucleic acids and lipids ${ }^{[23]}$

The results of the present work showed that, intraperitoneal administration of zinc sulphate, nicotinic acid or oral Nigella Sativa oil with oral ethanol resulted in an increase, in the gastric glutathione content which was reduced after oral ethanol alone. The mechanism of action of zinc sulphate may be due to stimulation of prostaglandin synthesis $^{[24]}$. Moreover the ulcerative effect of ethanol causes neutrophil infiltration which may be involved in gastric ulceration through production of oxygen free radicals. Zinc sulphate decreases the neutrophilic infiltration which may be attributed to the antiinflammatory and anti- oxidative properties of zinc ${ }^{[25]}$. In addition zinc sulphate reduces the superoxide radicals and inhibits lipid peroxidation in vitro and vivo ${ }^{[26]}$. Also zinc compounds prevent gastric ulceration in different experimental models such as pyloric occlusion, reserpineinduced ulcer, necrotizing agentsinduced ulcer, platelet activating factor-induced ulcer and cold restraint induced ulcer ${ }^{[27]}$.

The mechanism of action of nicotinic acid on the gastric mucosal protection is due to stimulation of prostaglandin $\mathrm{E} 2^{[28]}$. Nicotinic acid 
stimulate the cytooxygenase pathway of arachidonic acid metabolism measured as prostaglandin $\mathrm{E}_{2}{ }^{[29]}$. Also it causes increase in the release of prostaglandin like substances from isolated perfused heart ${ }^{[28]}$. In addition prostaglandin posses potent antiulcer properties independent of their known inhibitory effect on the acid secretion $^{1221}$. Also the stimulation of mucus secretion by nicotinic acid may be due to prostaglandin dependent mechanism . Moreover prostaglandin F2 shown to be cytoprotective through stimulation of the secretion of soluble gel mucin glycoprotein in rats ${ }^{[29]}$.

Nigella Sativa oil caused significant increase in glutathione which is responsible for the antioxidative and cytoprotective effects ${ }^{[11]}$. The results also showed significant reduction of gastric histamine content. This was explained by Chrkravarty ${ }^{\text {[30] }}$ who proved that Nigella Sativa and one of its constituents (polythymoquinone) in relatively low concentration, Sativa oil induced inhibition of histamine release due to reduction of glutathione which may be due to inhibition of adenylate cyclase and stimulation of phosphodiesrase activity.

The protective effect of Nigella Sativa can be explained by glutathione induced increase in prostaglandin synthesis through prostaglandin synthase which is capable of synthesizing prostaglandin $\mathrm{E}_{2}$ after depletion of glutathione from the stomach $^{\mathbf{1 2 2 1}}$. In addition Nigella Sativa oil caused increase in gastric mucin which was proved by histological examination and has antiulcer effect $^{[12]}$.

\section{Conclusion}

It is concluded that zinc sulphate, nicotinic acid and Nigella Sativa oil protect the gastric mucosa from the ulcerative effect of alcohol. So patients with peptic ulcer can administrate these substances.

\section{Acknowledgment}

Great thanks to Dr. Karema El Desoky, Professor of pathology department, Tanta University for great help in the pathological part of this work.

\section{REFERENCES}

1- Abu-Sitta S, Shalaby A and Abd- El-Mottaleb A(2000): The gastrointestinal tract .In (Physiology of medical practice; (5):25-55,

2- Thomas K (2003): Alcoholism causes, incidence and risk factors. Alcoholism; (20):1-5,

3- Rcpoteil by Michigan society for medical research conference; (2003).

4- King JC (1990): Assessment of zinc status. J Nutr; 111:474.

5- Bcrt LV and Falchuk KH (1993): The biochemical basis of zinc physiology. Physiol Rev;7397.

6- Marchesini G, Fabbri A and Zolis M (1996): Zinc supplementation and amino acid nitrogen metabolism in patients with advanced cirrhosis. Hepatology;23:1804,

7- Vallee BL (1988): Zinc biochemistry, physiology, toxicology and clinical pathology, Biofactors;1-13.

8- Sharonova IN, Vorobjev VS and Haos HL (2000): Interaction 
between copper and zinc at GABA receptors in acutely isolated cerebellar cells of rat. British J of pharmacology; 130851 -856.

9- Mary .1, Malloy $M$ and John $P$ (2000a): Nicotinic acid, an agent used in hyperlipidemia. In Basis of clinical pharmacol; $7^{\mathbf{1 1 1}}$ ed 35:563-577.

10- Hassan $M$ and El-Dakhakhny M (1992): Effect of some Nigella Sativa constituents on chemical carcinogens in hamster cheek pouch. J Egypt.Soc Pharmacol Exp Ther; 2:657-677.

11- El- Kadi A, Kamlil $O$ and Tabnni A (1987): Nigella and cell mediated immunity. Arch AIDS Res;1:232-233,

12- El_Dakhakliny M, Abd ElHalim $M$ and AH SM (2000): Effect of Nigella Sativa oil on gastric secretion and ethanol induced ulcer. J Egypt Soc Pharmacol Exp Ther; 19(1):781.

13- Yamaguchi $M$, Yoshino $T$ and Okada S (1980): Effect of zinc on acidity of gastric secretion in rats. Toxicol Pharmacol; 54:562532.

14- Lomnicky Y, Haimov T, Luria MH, Friedman $M$ and Huffman A (2000): Pharmacodynamic effects of zafibrate and niacin combination, implication of administration. J Pharm Sci; 89 (8) 064-53.

15- Gamal H El- Sokkary (2001): Quantitative study on the effects of chronic ethanol administration of adult male rats. J Egypt Soc Pharm; 22(2):93-99

16- Varly 11 (1969): Method of acid determination in practical clinical biochemistry $^{\wedge^{\prime 1}}$ ed London herm;327-332.

17- Richard J (1959): Methods of serum glycoprotein. In Glick Methods of Biochemical Analysis. Volume 2 New York Inter-sciences Publishers INC;290-304.

18- Sanyal AR, Denath OK, Bhattacharya SK and Gode KD (1971): The effect of cyproheptadine on gastric acidity in peptic ulcer. Copenhagen, Denmark, Scandinavian University Books;312:8.

19- Lorenz W, Barth H, Kuschc J , Riemann H, Schnial A, Jatyka E, Mathis CH, Mutzcl $M$ and Werle E(1971): Histamine in pig: Determination, distribution, release and pharmacological actions, EurJ Pharmaeol; 14:155175.

20- Owcns CWl and Belcher RV (1965): A calorimetric micromethod for the determination of glutathione. Biochem .1; 94:705711 ,

21- Kinoshita M, Yamsaki K, Kokusenya $Y$ and Tamnki $M$ (1995): Relationship between gastro protective effect of locally active antiulcer agent and its binding to gastric mucosa in rats, Digestive diseases and sciences; 40(3):661-667.

22- Saloncn, I.; Pakarinen, P.; and Huhraniemi I (1992): Effect of chronic ethanol in expression of gonadotropin genes in male rat. Journal of pharmacol and Exp. Ther. 260: 463-467.

23- Vankolfshotcn AA, Hagelen EC, Jager $L$, Zandberg $P$, and Van Noordwjik J (1983): 
Protective effects of prostaglandins against ulcerogenic activity of alcohol during different stages of erosion development in rat stomach. Dig Dis;28:1027-l132.

24- Cooke AR (1972): Ethanol and gastric function. Gastroenterology; 62:283-288.

25- Navarro C, Bravo L, Carulla C and Bulbcna O 1994): Gastro toxic activity and inhibitory effects on gastric mucosal prostaglandin E2 production. Modification induced by treatment with zinc compounds. Prostaglandin, Essential fatty acids; 50(50):305-310.

26- Tsutusi Y, Nakamara Y, Yamaguhi S, Kawanaka $\mathbf{N}$ and Sato M(1999): Effects of zinc compounds on superoxid radicals and lipid peroxidation of rat gastric mucosa. Pharmacol; 58(4):209-219.

27- Hao $Q$ and Marct W (2005): Imbalance between pro-oxidant and pro-antioxidant functions of zinc in disease. J Alzheimers Dis; 8 (2):161-70.

28- Scepovic $Z$ and Radamanovic BZ (I984): Interaction between reserpine and non steroidal antiinflammatory agents in producing ulcer in rats. Eur J Pharmacol;28:445-448.

29- Kaijser $L$ and Wennmalm $A$ (1978): Nicotinic acid stimulates prostaglandin synthesis in rabbit heart without releasing noradrenalin. Acta Physiol Scand;102:246-247.

30- Saarekes V, Miicfia I, Sicvi E and Riutta A(1999); Nicotinic acid and pyridoxine modulate arachidonic acid metabolism in vitro and vivo in man. Pharmacol-toxicol; $\quad 84(6)$ :274280.

31- Chrkravarty N(1993); Inhibition of histamine release from mast cells by Nigella. Ann Allergy;70(3\}:237-242. 


\section{دراسة عن التأثير الواقى لسلفات الزنك ، حض النيكوتينك وزيت الحبة}

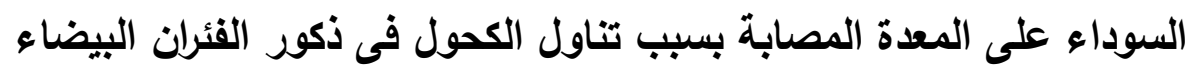

$$
\begin{aligned}
& \text { محموعبد الحميد الغريب- قسم الفسيولوجيا - كلية الطب } \\
& \text { ثناء أحمد الصصرى- قسم العقاقير -كلية الصيدلة }
\end{aligned}
$$

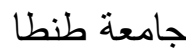

يهدف هذا البحث إلى دراسة التأثير الواقى لكل من سلفات الزنك ، حمض النيكوتينك

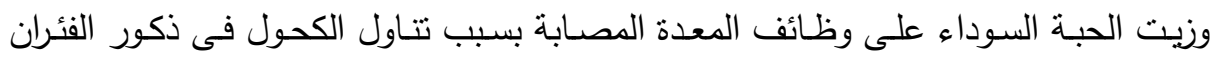

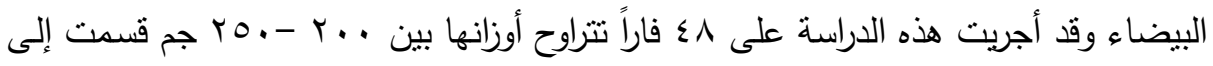

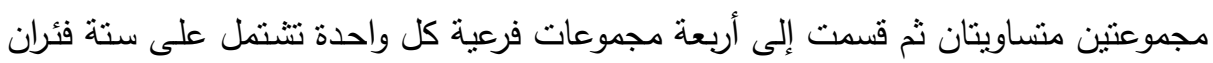
مجموعة (أ) مجناري الأولى: حقنت الفئران بمحلول ملح فى الغشاء البريتونى الثانية: حقنت الفئران بسلفات الزنكاء

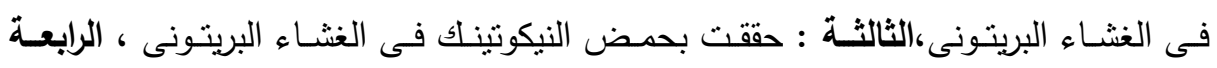
: بأعطيت زيت حبة البركة بالفم لددة أسبوعين.

مجموعة (ب) قسمت هذه الهجموعة أيضاً إلى أربة مجموعات منساوية

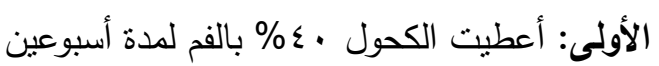

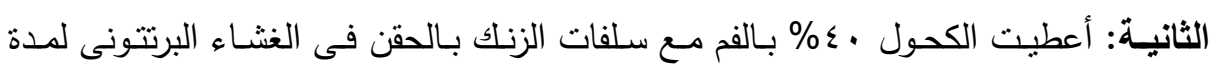
أسبوعين.

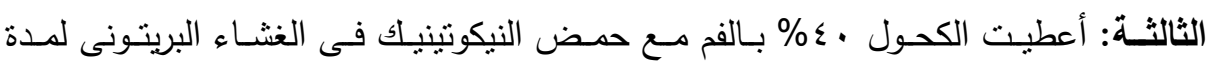
أسبوعين. الرابعة: أعطيت الكحول بالفم •ـ \% مع زيت حبة البركة بالفم لددة أسبوعين.

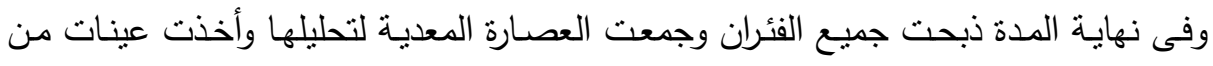
جدار المعدة وذاللك لفحصها. 
وقد تبين من نتائج هذه الدراسـة أن تتاول سلفات الزنكك أو حمض النيكوتينيك أو زيت حبة البركة يسبب زيادة ذات دلالمة إحصائية فى نسبة المخاط، الجلوتاثيون وإنخفاض ذات ذات دلالية إحصائية فى كل من حجم العصارة المعدية ، نسبة الببسين والأحماض المعدية والهيستامين فى الفئران المصابة بسبب تتاول الكحول كما وجد من الفحص الهيستوبانولوجى عدم وجود نزيف أو ورم مع زيادة سمك طبقة المخاط والتئام القرح الموجودة فى جدار المعدة.

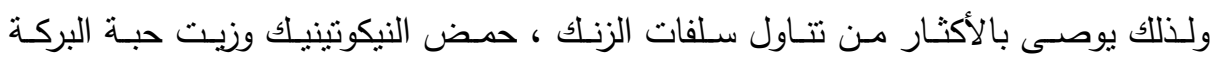
للمرضى الذين يعانون من قرحة المعدة خصوصا فى حالات تعاطى الكحول. 